\title{
Marketing Management Skill of Mangosteen Farmer
}

\author{
Reny Andriyanty ${ }^{1)}$, Haswan Yunaz ${ }^{2}$, Dodi Wahab ${ }^{3)}$, Tagor Rambey ${ }^{4)}$, Andi Masnang ${ }^{5)}$ and Aisyah ${ }^{6)}$ \\ ${ }_{1,2,3,4)}$ Departement of Economic, Institut Bisnis \& Informatika Kosgoro 1957. \\ Jl.M.Kahfie II No, 33 Jagakarsa South Jakarta, Indonesia \\ ${ }^{5)}$ Department of Agrotechnology Faculty of Agriculture, Nusa Bangsa University \\ $\mathrm{Jl}$,Baru km.4 Bogor,Indonesia \\ ${ }^{6)}$ Department of Agrotechnology, Gunadarma University Jakarta \\ Jl. Margonda Raya 100, Depok, West Java, Indonesia
}

\begin{abstract}
The purpose of the study is to measure the influence of internal factors, external factors and the technology utilization on marketing management skill of manggosteen farmers in Bogor. The respondent farmers were 60 farmers who are farmer group member and minumun 0,5 hectare land area landowners. The research model was analyzed by structural equation model which includes four latent variables. Empirical results show that the management skill of Bogor mangosteen farmers is average. The internal factor, individually the highest effect was motivation. The highest effect of external factor was goverment assistance in market information. The highest effect of technology utilization was internet utilization. The marketing managerial skills, the data shown that place was the highest variable. The internal factor and technology ability were significant and indicated positive correlation. Fifty nine percents farmer marketing capacity explained by internal, external factor and technology skill. Based on the outer loading analysis, the most influential manifest internal factor variable was farming interest. The influential manisfest variable was goverment assistance in market information. The most influential manifest of technology ability variable was transportation and communication utilization. The variable that influences the marketing management skill, the most is placing.
\end{abstract}

Keywords:- Marketing Management, Farmer Skill, Mangosteen.

\section{INTRODUCTION}

Nowadays the farmer marketing capability became main aspect for their welfare. Research of Naminse and Zhuang found that the farmer's social-cultural capability become the primary factor of entrepreneurship growth. That factor was also significantly impacts the rural poverty in Guangxi Province China (1). Management skill for farmer was significantly importance to nation economics (2) and significantly, management can increase the efficiency and effectiveness of agriculture (3). Base on Indonesia Statistic Berau from year 2013 till 2017, the mangosteen farmer exchange rate has flat tendency. Meanwhile base on FAO in the same period, data of the mangosteen producer and consumer price indices has rising trend. The data comparison shown on figure below:

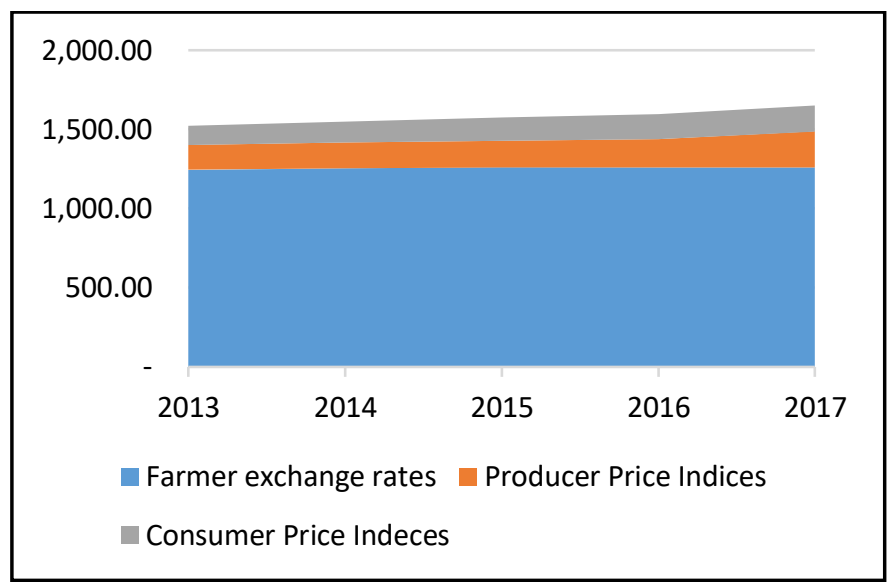

Fig 1:- The data of Indonesia mangosteen farmer exchange rates, International producer price indices and international mangosteen consumer price indeces.

Source: The farmer exchange rate from BPS (2019)

The producer and consumer price indices from FAO (2019).

The farmer's enterpreneurship influenced by technical and non-technical factor. The one of non-technical factor was rational boundary in mangosteen marketing management. That limitation used by middle trader and exporter with purpose to get bigger profit. (Oktini, 2018). The gap between producer and consumer price indices is margin for the broker (5). The circumstances declare that the rising price in consumer level, does not rise the farmer income. To escalate the farmer income, the marketing skill become a main factor (Rabbi et al., 2019; Erlangga, Purwadaria, \& Firdaus, 2012; FAO Diversification Booklet 16, 2010). In Canada, some of studies on against the agriculture challenges consists of three main things, such as: 1) the skills that related to the ability to acquire, organize and access the information, 2) the expertise in making the right business decisions, and 3) the expertise that related to the ability to organize all resources on the decision implementation. Those three main things realtionship was guided farmers to do the right management, meanwhile first expertise and second directed the farmers to do right business. All those things became critical factors for the success for farmers (http://www5.agr.gc.ca). Empirically, farming management is related to sustainability itself (8). 
The marketing management skill will help farmer to access the better market and price. Empirically many studies pointed that the Indonesia farmer management skill is low (Harahap, Sriyoto, \& Yuliarti, 2018; Veronice, Helmi, Henmaidi, \& Arif, 2018; Jaya, Sarwoprasodjo, Hubeis, \& Sugihen, 2017; Suasih \& Yasa, 2017; Quincieu, 2015; Sumarauw \& Soegoto, 2014; Patkar, Natawidjaja, \& Widyastuti, 2012; Pasaribu, 2010). This is in accordance with the conditions of mangosteen farmers in Bogor whereas the Republic Indonesia Agriculture Ministry, in year 2003 declared that mangosteen is a west Java primary imported oriented fruit. Astuti, Marimin, Poerwanto, Machfud, \& Arkeman, (2010) declared that the west Java mangosteen production actitivy was not efficient to international competetion and needed to involving organization selection in order to rise the Bogor mangosteen competitiveness. Smallholders farmer's participation in marketing channel choice is limmited by low volume of produce, presence of middleman, perceived low prices in local market and lack of information (12). To increase farmers 's opportunities in the market need various things affect farmers' participation (Valliant, Ruhf, Gibson, Brooks, \& Farmer, 2019; de Krom, 2017; Utaranakorn \& Yasunobu, 2016; Entz et al., 2015; Derks, van Werven, Hogeveen, \& Kremer, 2014;)

Basicly, the farmer marketing management skill is influenced by internal, external factor and technology utilization. The internal factor are motivation, farming interest, learning skill, positive perspective and farmer's diligance. The motivation and farming interest become first factor. If their motivation and interest are high, they will enhance their own management skill (May, Arancibia, Behrendt, \& Adams, 2019: Kragt, Dumbrell, \& Blackmore, 2017; Mayasari, Sente, \& Ammatilah, 2015). The learning skill of Bogor mangosteen farmer are low. Their average education is primary school. Farmer also must have positive perspective because it push farmer to optimalize their farm. Lima and Müller (2017) mentioned that the education and experience of small business owners indirectly affect the cognitive ability of small business owners to open new market opportunities. Damke, Junior, Gimenez dan Damke (2018) also mentioned related to the strategic management of small-scale enterprises was very dependent on the scope of their knowledge, the higher their knowledge, the better their management strategic ability. They become internal factor that can expand the marketing managerial skill (Panpakdee \& Limnirankul, 2018; Sumner, von Keyserlingk, \& Weary, 2018; Sutherland et al., 2017; Terano, Mohamed, \& Din, 2016; Diab, 2015; GithithoMuriithi, 2010). And diligance, the mangosteen is seasonal and yearly fruit and diversificate with pala, padi and other plant. The farmer diligance will rise the mangosteen quantity. The farmer decide the diversification to increase revenue (Morris, Henley, \& Dowell, 2017; Pisani \& Scrocco, 2016; Ibrahim, Dorina, \& Abdelrazek, 2014; Chowdhury \& Khairun, 2014; Wang, 2010). It is supported by Pisani and Scrocco's research that mentioned a downward trend in farmers' income (in cotton) related to product specialization (28).
The external factor are farmer organization existance, goverment assisstance in production, price, capital accessibility, market information and quality assurance. Basically, organizations existance will be interconnected with human resources (29). Farmer must implement the good governance farming to run their farm business (30). Empiricaly, Bogor mangosteen farmers tend to depend their farm on government policy. The goverment assitance plays a important role (31). Jean Tirole, Noble prize awarded in year 2014, declared that in example if the farmer are poorly informed meanwhile the trader plays negative extarnalities the goverment must apply public intervention (32). Many studies showed the government's role success in improving the farmers welfare (Rose et al., 2019; Baloch \& Thapa, 2019; Kansiime, van Asten, \& Sneyers, 2018; Zasada et al., 2017;Cabral, Favareto, Mukwereza, \& Amanor, 2016, M. Badrul Haider \& Akhter, 2014). One aspect of government involvement in improving farmers' welfare is price incentive policy. Price incentives are a major consideration for sustainability of production, so many traditional farmers lack the knowledge and expertise to make important decisions relating to prices that tend to decide on the basis of intuition or simply follow other farmers' decisions (Kustiari, \& Purba, 2012).

Technology can make farmers accessing the market information (Barhatov, Campa, \& Pletnev, 2018; Raungpaka \& Savetpanuvong, 2017). In understanding that the Bogor mangosteen farmers are small scale entrepreneurs, technology utilization can help farmer to enhance their value added into market (41). It is importance because enhancing the marketing management skill (Morris, Henley, \& Dowell, 2017; Sianipar, Yudoko, Adhiutama, \& Dowaki, 2013). Empiricaly technology utilization by farmer is low and corelated (Andriyanty \& Humaira, 2016; Icc, 2016). The technology aspects analyze from three aspects: communication (handphone using), transportation (vehicle using), and internet (internet access via cellphone).

Farmers are entrepreneurs for their farm. They should have managerial skills (Agbolade Obasan, 2014; R. Radfar. N. Rezaei-Malek, 2012), particularly in marketing. Kotler stated that marketing management is about applying the concept of market segment targeting the market appropriately, effectively and efficiently, maintain and increase the number of consumers through the creation, delivery and communication of consumer values. Regarding to creating, delivering and communicating of consumer value, farmers must apply the marketing mix through understanding the concepts of product, price, place, promotion, people, process, and physical evidence (46). The better of marketing managerial skills of farmers, the better their income (Kaleka \& Morgan, 2019; Kyomugisha, Sebatta, \& Mugisha, 2018 ; Obradović, Kostić, \& Mitrović, 2016; Abishovna, 2014; Hussin, Alias, \& Ismail, 2013).

Based on the things outlined above, all maters above are important for increasing the farmer marketing managerial skill. Many studies declraed that Indonesian farmer have low management skill, but how low it is? 
This research purpose are to measure the level of farmer's marketing management and to measure the influence of internal factors, external factors and the technology utilization on marketing management skill of manggosteen farmers in Bogor. The expectation of this study is agriculture human resources mapping.

\section{RESEARCH METHOD}

The location of the study were in Bogor covering 9 villages covered Leuwiliang sub-district (Barengkok, Karacak and Pabangbon village); Cigudeg sub-districts (Sukaraksa and Bunar village); Jasinga sub-district (Pangradin and Jugalaya village). The respondent farmers were 60 farmers who are farmer group member and minumun 0,5 hectare land area landowners. The participation in farmer organizations is fundamental to marketing managerial skill (Utaranakorn \& Yasunobu, 2016; Gangai \& Agrawal, 2015). The data type were used primary data and to measure the level of marketing management skill of respondents was designed with positive Linkert scale (from 1-5). Respondents were asked to assess their skill based on the research questionnaire. The lowest value is rated 1 , and the highest is rated 5 . The level of approval in this research was the farmer opinion with gradation and weighted values according to the following table:

\begin{tabular}{|c|c|}
\hline $\begin{array}{c}\text { The farmer decision } \\
\text { gradation }\end{array}$ & Weighted value \\
\hline Very high & 5 \\
\hline High & 4 \\
\hline Average & 2 \\
\hline Low & 1 \\
\hline Very low & 3 \\
\hline
\end{tabular}

Table 1:- The gradation and weighted values of farmers marketing management capability.

The general theory of linear models is declared valid if the observed variables are random. This assumption has implications for the analysis of the regression model, so that a structured and consistent model is developed in the design of the model equation matrix. Stuctural analysis models (SEM) are categorized as multivariate statistics dependencies that allow the analysis of one or more independent variables into latent variables with estimated measurement errors (Timm, 2007). This research is socioeconomic research using farmer behavior data which includes four latent variables. The first endogenous latent variable is the internal factor, the second endogenous variable is external factor, the third is technology application and the exogenous latent variable is the farmer's marketing management skill. The reserach modeling is approached with SEM (54). The conversion equation path diagram consist of two model: outer model and inner model. The mathematical model equation is:

$$
\eta=\tau_{1} \xi_{1}+\tau_{2} \xi_{2}+\tau_{3} \xi_{3}+t_{1}
$$

Where $\eta=$ the farmer marketing management skill; $\tau_{1}=$ coefficients associated with internal factor; $\xi_{1}=$ internal factor; $\tau_{2}=$ coefficients associated with external factor; $\xi_{2}=$ external factor; $\tau_{3}=$ coefficients associated with external factor; $\xi_{3}=$ external factor; $\mathrm{t}_{1}=$ error of exogenous latent variable. All datas analyzed by statitical software SmartPLS.

The farmer marketing management skill as exogenous latent variable be affected by three endogenous latent variables. The first endogenous latent variable, internal factor analyzed by the following manifest variables: motivation, farming interest, learning capability, positive perspective and farmer's diligance. The second is external factor, used approach by six manifest variables: organization existance, goverment assistance in production, goverment assistance in price, goverment assistance in market information, goverment assistance in quality assurance, and goverment assistance in capital accessibility. The third endogenous latent variable is technology application. Its manifest variables are communication technology utilization, transportation technology utilization and internet technology utilization. The latent endogenous variables was farmer marketing management skill. It analyzed by seven manifest variables: product, price, place, promotion, process, people and phycisal evidence. Based on the analysis of construct reliability and validity, all values of the loading factor are reliable and valid. The specification for measuring all manifest variables shown in figure below: 


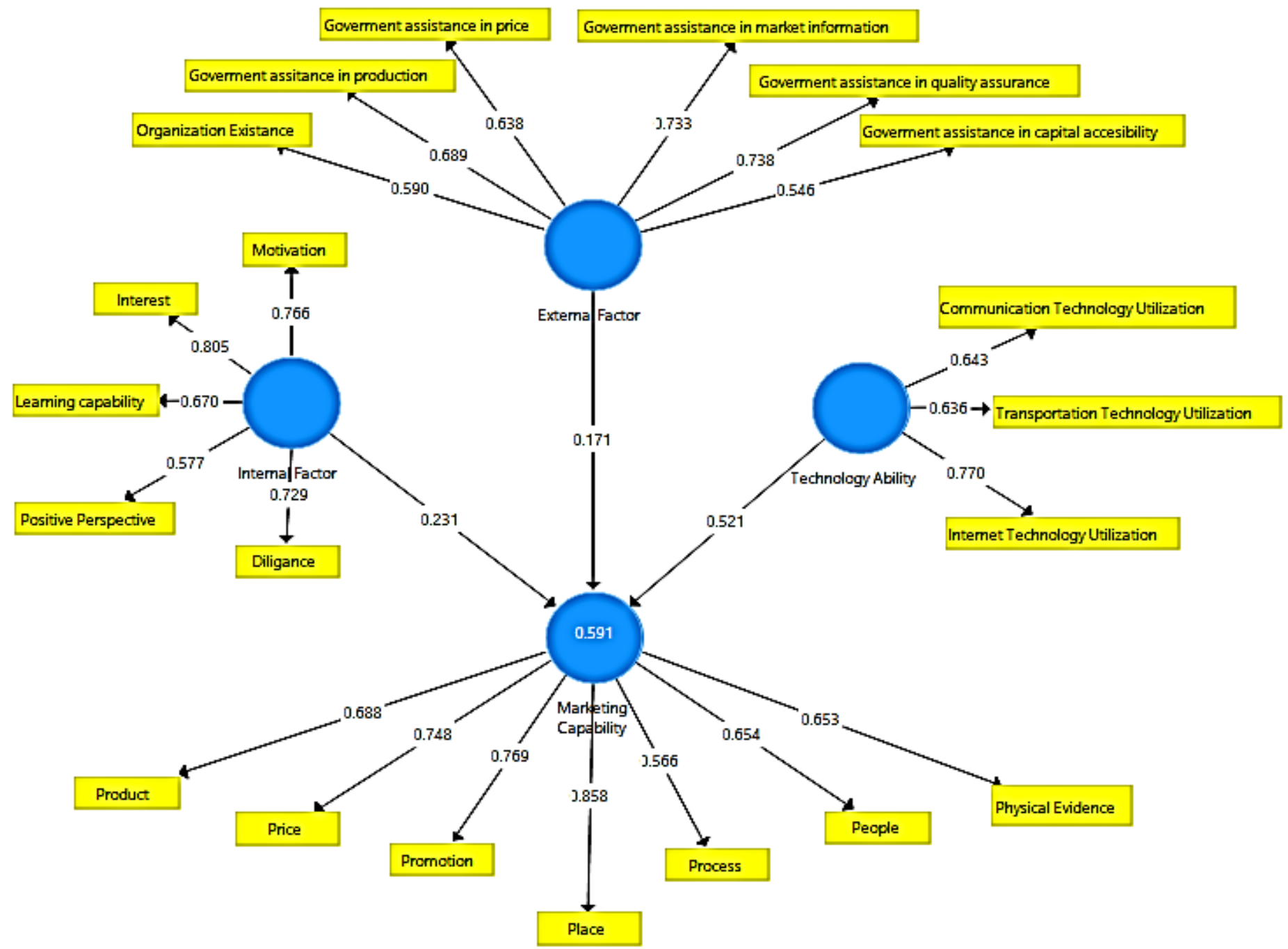

Fig 2:- The construct reliability and validity.

\section{RESULTS \& DISCUSSION}

The internal factor, individually the manifest variable that has the highest score was 3,65 on motivation $(\mathrm{SD}=0,68)$. The lowest score was positive perseptive $=3,13$ and $\mathrm{SD}=1,00$ ). All manifest variables have an average number of three. Empirically in the research field, farmers do mangosteen cultivation because of heredity. The internal factors tend to be weak factor in determining the farmer's marketing managerial skill. The highest score of external factor was organization existance with value 3,27 and standard deviation $=0,78$. The lowest score was goverment assistance in quality assurance with value 3,27 and standard deviation $=0,78$. Actually goverment assitance is given in the form of the role of village agricultural instructors. Farmer can be asked everything related with production, and quality assurance. The goverment assitance in price is also given but frequently not valid. The goverment assitance in capital accessibility and market information were limited At in the end they were always dependent on the middle man. The technology utilization, the highest score were transportation utilization with value 3,85 (standard deviation=0,97). The lowest score was internet utilization with value 2,72 (standard deviation=1,01). In general, farmers already have a mobile phone but it is limited to the telephone and text functions. Their cellphone can not access the internet because of limited capital and low urge of internet technology itself. For mangosteen transportation, farmers have optimized their motorbikes. The marketing managerial skills, the data shown that production was the highest variable with number 3,95 (standard deviation=0,97). The lowest score was promotion with value 2,88 (standard deviation=1,06). In production aspects: the farmers were able to sort and grading, but it required a further cost than if they sold directly to middle/local trader (in local languange middle/local trader call as ijon). These conditions made farmers sold their mangosteen bulky. Farmers accepted the price information when the harvest arrived, but they did not have enough time to process that information properly. It caused the farmer limitations to access on price and procedures of export. For more details datas could be seen in the following table 2 below. 
ISSN No:-2456-2165

\begin{tabular}{|c|c|c|c|c|}
\hline Indicators & Minimum & Maximum & Mean & Standard Deviation \\
\hline Farmer motivation & 2 & 5 & 3,65 & 0,68 \\
\hline Interest in Farming & 2 & 5 & 3,38 & 0,85 \\
\hline Learning capability & 1 & 5 & 3,38 & 0,92 \\
\hline Positive Perspective & 1 & 5 & 3,13 & 1,00 \\
\hline Farmer Diligance & 2 & 5 & 3,35 & 0,84 \\
\hline Organization Exisstance & 2 & 5 & 3,83 & 0,91 \\
\hline $\begin{array}{c}\text { Goverment Assistances in } \\
\text { Production }\end{array}$ & 2 & 5 & 3,70 & 0,87 \\
\hline Goverment Assistances in Price & 1 & 5 & 3,48 & 0,75 \\
\hline $\begin{array}{c}\text { Goverment Assistances in Capital } \\
\text { Accessbility }\end{array}$ & 2 & 5 & 3,45 & 0,05 \\
\hline $\begin{array}{c}\text { Goverment Assistances in Market } \\
\text { Information }\end{array}$ & 2 & 5 & 3,70 & 0,81 \\
\hline $\begin{array}{c}\text { Goverment Assistances in Quality } \\
\text { Assurance }\end{array}$ & 2 & 5 & 3,27 & 0,78 \\
\hline $\begin{array}{c}\text { Communication Technology } \\
\text { Application }\end{array}$ & 1 & 5 & 3,73 & 0,86 \\
\hline $\begin{array}{c}\text { Transportation Technology } \\
\text { Application }\end{array}$ & 2 & 5 & 3,85 & 0,97 \\
\hline Internet Technology Application & 2 & 5 & 2,72 & 1,01 \\
\hline Managerial skill in Production & 2 & 5 & 3,95 & 0,77 \\
\hline Managerial skill in Pricing & 2 & 5 & 3,05 & 1,00 \\
\hline Managerial skill in Promotion & 2 & 5 & 2,88 & 1,06 \\
\hline Managerial skill in Placing & 2 & 5 & 3,63 & 0,71 \\
\hline Managerial skill in Processing & 2 & 5 & 3,65 & 0,78 \\
\hline Managerial skill in People relation & 2 & 5 & 3,48 & 0,75 \\
\hline Managerial skill in Physical \\
Evidence & 2 & 5,17 & \\
\hline
\end{tabular}

Table 2:- The descriptive data.

The further analysis continues with the construct reliability and validity of all latent variables. The composite realiability value showed the construct for all latent variables were realibel and valid. The data shown on table below.

\begin{tabular}{|c|c|c|c|}
\hline & $\begin{array}{c}\text { Cronbach's } \\
\text { Alpha }\end{array}$ & Rho_A & $\begin{array}{c}\text { Composite } \\
\text { Realiability }\end{array}$ \\
\hline External Factor & 0,740 & 0,749 & 0,820 \\
\hline Internal Factor & 0,773 & 0,803 & 0,837 \\
\hline $\begin{array}{c}\text { Technology } \\
\text { Ability }\end{array}$ & 0,454 & 0,442 & 0,725 \\
\hline Marketing Skill & 0,832 & 0,840 & 0,876 \\
\hline
\end{tabular}

Table 3:- The construct reability and validity test.

Goodness of fit model is measured using R-square latent variables of farmer's marketing capacity. R-square value bigger than 0 indicates the model has predictive relevance otherwise if the $\mathrm{R}$-square value smaller or same with 0 indicates the model has less predictive relevance. Based on the analysis of the R-square value obtained 0.591, which concluded that the model is good fit. It shows 59 percents farmer marketing capacity explained by internal, external factor and technology skill. Based on the path analysis and total effects, The internal factor and technology ability were significant and only external factor latent variable was not significant. The internal factor, original sample estimate value 0,231 indicated positive correlation. The original sample estimate value for technology ability was 0,521 and indicated positive correlation also. The path analysis data can be seen in the following table.

\begin{tabular}{|c|c|c|c|c|c|c|}
\hline & $\begin{array}{c}\text { Original } \\
\text { sample }\end{array}$ & $\begin{array}{c}\text { Sample } \\
\text { Mean }\end{array}$ & $\begin{array}{c}\text { Standard } \\
\text { Deviation }\end{array}$ & $\begin{array}{c}\text { T } \\
\text { Statistic }\end{array}$ & P Value & Conclusion \\
\hline External Factor $\rightarrow$ Marketing skill & 0,171 & 0,175 & 0,125 & 1,376 & 0,085 & insignificant \\
\hline Internal Factor $\rightarrow$ Marketing Skill & 0,231 & 0,241 & 0,122 & 1,899 & 0,029 & significant \\
\hline Technology Ability $\rightarrow$ Marketing Skill & 0,521 & 0,522 & 0,141 & 3,687 & 0,000 & significant \\
\hline
\end{tabular}

Table 4:- The path analysis. 
The structural equation model formulated as follows:

$$
\eta=0,171 \xi_{1}+0,231 \xi_{2}+0,521 \xi_{3}+t_{1}
$$

The internal factor and technology ability influenced the marketing managerial skill. It declared that it can be build from their internal factor and escalate the technology ability instead of external factor escalation.

\begin{tabular}{|c|c|c|c|c|c|c|}
\hline & $\begin{array}{l}\text { Original } \\
\text { sample }\end{array}$ & $\begin{array}{l}\text { Sample } \\
\text { Mean }\end{array}$ & $\begin{array}{l}\text { Standard } \\
\text { Deviation }\end{array}$ & $\begin{array}{c}\mathrm{T} \\
\text { Statistic }\end{array}$ & $\begin{array}{c}\mathrm{P} \\
\text { Value }\end{array}$ & Conclusion \\
\hline Farming Interest $\leftarrow$ Internal Factor & 0,805 & 0,787 & 0,143 & 5,632 & 0,000 & significant \\
\hline Motivation $\leftarrow$ Internal Factor & 0,766 & 0,726 & 0,148 & 5,182 & 0,000 & significant \\
\hline Diligance $\longleftarrow$ Internal Factor & 0,729 & 0,724 & 0,107 & 6,806 & 0,000 & significant \\
\hline Learning skill $\leftarrow$ Internal Factor & 0,670 & 0,616 & 0,200 & 3,353 & 0,000 & significant \\
\hline Positive Perspective $\leftarrow$ Internal Factor & 0,577 & 0,547 & 0,199 & 2,898 & 0,000 & significant \\
\hline $\begin{array}{l}\text { Goverment assistance in market information } \\
\leftarrow \text { External Factor }\end{array}$ & 0,733 & 0,725 & 0.104 & 7,075 & 0,000 & significant \\
\hline $\begin{array}{c}\text { Goverment assistanve in production } \leftarrow \text { External } \\
\text { Factor }\end{array}$ & 0,689 & 0,686 & 0,095 & 7,246 & 0,000 & significant \\
\hline Goverment assistanve in price $\leftarrow$ External Factor & 0,638 & 0,596 & 0,1541 & 4,139 & 0,000 & significant \\
\hline Organization Existance $\leftarrow$ External Factor & 0,590 & 0,579 & 0,10 & 4,200 & 0,000 & significant \\
\hline $\begin{array}{c}\text { Goverment assistance in capital accesibility } \\
\leftarrow \text { External Factor }\end{array}$ & 0,546 & 0,531 & 0,138 & 3,953 & 0,000 & significant \\
\hline $\begin{array}{c}\text { Internet Technology Utilization } \leftarrow \text { Technology } \\
\text { Ability }\end{array}$ & 0,770 & 0,757 & 0.096 & 8,042 & 0,000 & significant \\
\hline $\begin{array}{c}\text { Communication Technology Utilization } \\
\leftarrow \text { Technology Ability }\end{array}$ & 0,643 & 0,635 & 0,156 & 4,129 & 0,000 & significant \\
\hline $\begin{array}{l}\text { Transportation Technology Utilization } \leftarrow \text { Technology } \\
\text { Ability }\end{array}$ & 0,636 & 0,625 & 0,133 & 4,783 & 0,000 & significant \\
\hline Place $\leftarrow$ Marketing Skill & 0,858 & 0,847 & 0,072 & 11,867 & 0,000 & significant \\
\hline Promotion $\leftarrow$ Marketing Skill & 0,769 & 0,765 & 0,058 & 13,147 & 0,000 & significant \\
\hline Price $\leftarrow$ Marketing Skill & 0,748 & 0,737 & 0,098 & 7,617 & 0,000 & significant \\
\hline Product $\leftarrow$ Marketing Skill & 0,688 & 0,676 & 0,097 & 7,064 & 0,000 & significant \\
\hline People $\leftarrow$ Marketing Skill & 0,654 & 0,651 & 0,093 & 6,997 & 0,000 & significant \\
\hline Physical Evidence $\leftarrow$ Marketing Skill & 0,653 & 0,653 & 0,128 & 5,116 & 0,000 & significant \\
\hline Process $\leftarrow$ Marketing Skill & 0,566 & 0,540 & 0,169 & 3,343 & 0,000 & significant \\
\hline
\end{tabular}

Table 5:- The Outer loading analysis.

Based on the outer loading analysis table below, all manifest variables were significant. The first latent exogenous variable that influenced the marketing management skill was internal factor. The most influential manifest internal factor variable was farming interest $(0,802)$. The farming interest plays a critical role in farmer marketing skill escalation especially young farmer (55). The other influential manifest variable were motivation, farmer diligance, their learning skill and positive perspective. All variables is a fundamental factor to improve the ability of farmers in mangosteen farming and their scores were average. The empirical evidence showed that the effect of mangosteen farmer farmer motivation $=0,766$; The farmer diligance effect $=0,729$; the learning skill effect $=0,670$ and positive perspective effect $=0,577$. The second latent exogenous variable that influenced the marketing skill was external factor. The influential manisfest variable was goverment assistance in market information with value 0,733 . The effect values in a row were goverment assistance in production $(0,689)$, goverment assistance in price $(0,638)$, organization existance $(0,590)$ and goverment assistance in capital accesibility $(0,546)$. The most influential manifest of technology ability variable was the internet utilization with effect $=0,770$ and followed by communication and transportation utilization. The communication effect $=$ 0,643. Meanwhile the tranportation utilization was low with effect $=0,636$. Generally the farmers used mobile phones in a simple way even though limited to the telephone calls and texting to traders. They do not connect with the internet. Farmers also have difficulty operating the internet. This is related to the average age of farmers who are old and low adoption. This condition explain by Jamaluddin's reasearch in year 2013 that Indian farmer are in still in infant stage in internet-using. Although there has been a lot of training given to farmers, the main constraints are poor internet connectivity, costs, and lack of organization (56). Most farmer utilized their motorcylce to transport the mangoosteen. Farmer always relies on his mangosteen transportation process to middle/local traders. 
They did not develop their transportation with the bigger vehicles, due cost reason. Bigger vehicles mean bigger cost and farmers do not want to endure that cost.

The endogenous latent variable was marketing management skill. It consisted of six manifest variables with value average. The most influential manifest variable was place with effect $=0,858$. The other manifest variables: Promotion effect $=0,769$; price effect $=0,748$, people effect $=0,654$; physical evidence effect $=0,653$ and process effect $=0,566$. The production became main aspect because fair production process will guarantee the better product (Abdullah \& Hoetoro, 2011). Bogor mangosteen farmer must be able to change the paradigm towards modernizing farming (58). Research of Allahyari, Saburi dan Keshavarz (p:65) also explained that in the area the farmer ability to sell their products directly to consumers has the lowest value (59). Lobantiu \& Lobantiu (p.550) said that, the most small business owners who tend to do direct sales activities only 38 percent, the rest tend to hand over sales to other marketing agencies (60) . This showed that farmers prefer to sell their products to other marketing institutions rather than directly selling to the consumers. The farmers focused more on production activities than on marketing activities. They bounded for accessing and processing the complete information in uncertainty circumstances. It positioned the farmer as price taker in mangosteen marketing system in Bogor. This condition caused the rentseking exploration by the marketing agency institutions. That behavior plus the low capital, the high transportation costs and the risk of fruit damage, the absence of financial institutions at the village that can not ensure the availability of funds for farmers to fulfill their life necessities, forced farmers to sell their mangosteen to merchant collectors or middle/local trader. Those things becomed a driving factor why farmers were not ready to become a mangosteen marketing institution directly. Farmers consciously declared that their mangosteen fruit has not met the export requirement and was forced to accept the price offered by the marketing agency.

Basically, farmers want to be able to sell mangosteen independently and have tried to improve product quality. But they are constrained by their daily needs cost. To fulfill their daily needs, farmers mortgaged their immature mangosteen to local traders. The traders will estimate the price of the mangosteen as they wish and farmer must accept its price. In this circumstances occur rentseeking. The rentseeking condition can be surmounted by increasing of internet technology utilization farmer ability and capital assistance from the government. The govenment assitance in initiating the existence of financial institutions for farmers can be the right solution related to rentseeking. The one of most priority strategies of mangosteen agriculture are post-harvest infrastructure through cooperation with exporters and financial institutions, followed by the use of developed cultivation and postharvest technology to increase mangosteen productivity and improve its quality (61). The internet technology utilization enables farmers to sell mangosteen directly. This scheme shortens the marketing chain. It is more profitable for farmers. This is supported by Sianipar, Yudoko, Ashiutama and Dowaki's statement of increased utilization of the farming community towards technology which has an effect on sustainable development. This is what requires goverment involving (62).

Due to the low of farmer marketing management skill, it was found a solution that the farmer marketing skill should be developed. The developing of farmer's participation into market could be supported through subsidized price, stock storing, training, new technology introducing and enhance the role of local agricultural instructors (Rabbi et al., 2019; Toader \& Roman, 2015) It should be noted that with the marketing training, farmers can be trained to access information and make marketing decisions based on accurate information ("2013 Annual Report on FAO's projects and activities in support of producer organizations and cooperatives," 2013). The farmer with low endowment factor basically can rely on social capital which are tailored to farmers' characteristics (65). The inclusion of social capital in farming is expected to increase farmers' competence and innovation for their marketing management skill. The improvements in business skills, project management and information technology capabilities have a positive effect on sales and profits (66).

\section{CONCLUSION}

Overall Bogor mangosteen farmer's marketing managerial skill is at an average condition (value 3 on a scale of 1 to 5). The internal factor and technology ability were significant and indicated positive correlation. Fifty nine percents farmer marketing capacity explained by internal, external factor and technology skill. The most influential manifest internal factor variable was farming interest. The influential manisfest variable was goverment assistance in market information. The most influential manifest of technology ability variable was internet utilization. The endogenous latent variable influenced by manifest variable was place. That circumstances must be improved by increasing the internal factors of the farmers themselves instead of external factor development. And it must be followed by the development of technology application among farmers, especially the internet utilization.

\section{REFERENCES}

[1]. Naminse EY, Zhuang J. Does farmer entrepreneurship alleviate rural poverty in China? Evidence from guangxi province. PLoS One [Internet]. 2018;13(3):119. Available from: http://dx.doi.org/10.1371/journal.pone.0194912

[2]. Obi J, Ibidunni AS, Tolulope A, Olokundun MA, Amaihian AB, Borishade TT, et al. Contribution of small and medium enterprises to economic development: Evidence from a transiting economy. Data Br [Internet]. 2018;18:835-9. Available from: http://dx.doi.org/10.1016/j.dib.2018.03.126 
[3]. Skobelev PO, Simonova E V., Smirnov S V., Budaev DS, Voshchuk GY, Morokov AL. Development of a knowledge base in the "smart farming" system for agricultural enterprise management. Procedia Comput Sci [Internet]. 2019;150:154-61. Available from: https://doi.org/10.1016/j.procs.2019.02.029

[4]. Oktini DR. Analisis tentang kompetensi dan kinerja petani pembudidaya ikan kolam apung (ukm) di kabupaten bandung barat. :29-41.

[5]. Puspitasari AW. Farmer's Prosperity: How to Increase Farmer's Bargain Power (In Islamic Perspective). Procedia - Soc Behav Sci [Internet]. 2015;211(September):455-60. Available from: http://dx.doi.org/10.1016/j.sbspro.2015.11.060

[6]. Rabbi F, Ahamad R, Ali S, Ali A, Ahmad W, Ilyas A. Journal of the Saudi Society of Agricultural Sciences Determinants of commercialization and its impact on the welfare of smallholder rice farmers by using Heckman' s two-stage approach. J Saudi Soc Agric Sci [Internet]. 2019;18(2):224-33. Available from: https://doi.org/10.1016/j.jssas.2017.06.001

[7]. Fruit products for profit Fruit products for profit. 1810.

[8]. Holly MA, Gunn KM, Rotz CA, Kleinman PJA. Management characteristics of Pennsylvania dairy farms. Appl Anim Sci [Internet]. 2019;35(3):325-38. Available from: http://dx.doi.org/10.15232/aas.201801833

[9]. Harahap J, Sriyoto S, Yuliarti E. Faktor-Faktor Yang Mempengaruhi Pengambilan Keputusan Petani Salak Dalam Memilih Saluran Pemasaran. J AGRISEP. 2018;17(1):95-106.

[10]. Jaya MN, Sarwoprasodjo S, Hubeis M, Sugihen BG. Tingkat_Keberdayaan_Kelompok_Tani_pada_Pengel olaan. 2017;13(2).

[11]. Sumarauw J, Soegoto A. Analisis Manajemen Usaha Petani Dan Pertanian Di Kawasan Agropolitan Dumoga Untuk Menopang Ketahanan Pangan Nasional. J Ris Ekon Manajemen, Bisnis dan Akunt. 2014;2(4):233-45.

[12]. Kherallah M, Kirsten J. MSSD DISCUSSION PAPER NO . 41 THE NEW INSTITUTIONAL ECONOMICS : APPLICATIONS FOR AGRICULTURAL POLICY RESEARCH IN by MSSD DISCUSSION PAPER NO . 41 by Mylène Kherallah and Johann Kirsten Contact: Shirley Raymundo. 2001;(41).

[13]. Derks M, van Werven T, Hogeveen H, Kremer WDJ. Associations between farmer participation in veterinary herd health management programs and farm performance. J Dairy Sci. 2014;97(3):1336-47.

[14]. de Krom MPMM. Farmer participation in agrienvironmental schemes: Regionalisation and the role of bridging social capital. Land use policy [Internet]. 2017;60:352-61. Available from: http://dx.doi.org/10.1016/j.landusepol.2016.10.026

[15]. Valliant JCD, Ruhf KZ, Gibson KD, Brooks JR, Farmer JR. Fostering farm transfers from farm owners to unrelated, new farmers: A qualitative assessment of farm link services. Land use policy [Internet]. 2019;86(September 2018):438-47. Available from: https://doi.org/10.1016/j.landusepol.2019.05.004

[16]. Utaranakorn P, Yasunobu K. The mutual influence of managerial ability and social networks of farmers on participation in an organic vegetable group in Khon Kaen province, Thailand. Kasetsart J Soc Sci [Internet]. 2016;37(3):127-31. Available from: http://dx.doi.org/10.1016/j.kjss.2016.08.001

[17]. Entz MH, Kirk AP, Vaisman I, Fox SL, Fetch JM, Hobson D, et al. Farmer Participation in Plant Breeding for Canadian Organic Crop Production: Implications for Adaptation to Climate Uncertainty. Procedia Environ Sci. 2015;29(Agri):238-9.

[18]. Mayasari K, Sente U, Ammatilah CS. Analisis motivasi petani dalam mengembangkan pertanian perkotaan di Provinsi DKI Jakarta. Bul Pertan Perkotaan. 2015;5(30):16-24.

[19]. Sumner CL, von Keyserlingk MAG, Weary DM. How benchmarking motivates farmers to improve dairy calf management. J Dairy Sci [Internet]. 2018;101(4):3323-33. Available from: http://dx.doi.org/10.3168/jds.2017-13596

[20]. Sutherland LA, Madureira L, Dirimanova V, Bogusz M, Kania J, Vinohradnik K, et al. New knowledge networks of small-scale farmers in Europe's periphery. Land use policy [Internet]. 2017;63:42839. Available from: http://dx.doi.org/10.1016/j.landusepol.2017.01.028

[21]. Diab AM. Learning impact of farmer field schools of integrated crop-livestock systems in Sinai Peninsula, Egypt. Ann Agric Sci [Internet]. 2015;60(2):289-96. Available from: http://dx.doi.org/10.1016/j.aoas.2015.10.014

[22]. Githitho-Muriithi A. Education for all and child labour in Kenya: A conflict of capabilities? Procedia Soc Behav Sci [Internet]. 2010;2(2):4613-21. Available from: http://dx.doi.org/10.1016/j.sbspro.2010.03.739

[23]. Terano R, Mohamed Z, Din NSZ. Determinants of Farmers' Adoption of Clearfield Production System in Malaysia. Agric Agric Sci Procedia [Internet]. 2016;9:103-7. Available from: http://dx.doi.org/10.1016/j.aaspro.2016.02.133

[24]. Panpakdee C, Limnirankul B. Indicators for assessing social-ecological resilience: A case study of organic rice production in northern Thailand. Kasetsart J Soc Sci [Internet]. 2018;39(3):414-21. Available from: https://doi.org/10.1016/j.kjss.2017.07.003

[25]. Morris W, Henley A, Dowell D. Farm diversification, entrepreneurship and technology adoption: Analysis of upland farmers in Wales. J Rural Stud [Internet]. 2017;53:132-43. Available from: http://dx.doi.org/10.1016/j.jrurstud.2017.05.014

[26]. Ibrahim MAR, Dorina M, Abdelrazek I. How Rural Agricultural Development Projects (Animal Production) can Use Projects Benefits for Improving the Economics States of Farmers. Procedia Econ Financ. 2014;8(14):484-9.

[27]. Wang Y. Income uncertainty, risk coping mechanism and farmer production \& management decision: An empirical study from Sichuan province. Agric Agric Sci Procedia. 2010;1:230-40. 
[28]. Pisani E, Scrocco S. Building New Income Opportunities for Small-farmers in Peru: The Case of Native and Naturally Colored Cotton. Agric Agric Sci Procedia [Internet]. 2016;8:426-32. Available from: http://dx.doi.org/10.1016/j.aaspro.2016.02.039

[29]. Armutlulu IH, Noyan F. A multilevel model of organizational commitment. Procedia - Soc Behav Sci. 2011;30:2139-43.

[30]. Warganegara D, Saputra M, Anggraini Y. StateOwned Enterprises and Corporate Governance Strength: Evidence from Indonesia. Int J Manag Bus Res. 2013;3(4):325-35.

[31]. Dick WJA, Wang W. Government interventions in agricultural insurance. Agric Agric Sci Procedia [Internet]. 2010;1:4-12. Available from: http://dx.doi.org/10.1016/j.aaspro.2010.09.002

[32]. Royal THE, Academy S, Sciences OF. Scientific Background on the Sveriges Riksbank Prize in Economic Sciences in Memory of Alfred Nobel 2010 compiled by the Economic Sciences Prize Committee of the Royal Swedish Academy of Sciences Markets with Search Frictions. Search. 2010;50005(October):0-34.

[33]. Rose DC, Sutherland WJ, Barnes AP, Borthwick F, Ffoulkes C, Hall C, et al. Integrated farm management for sustainable agriculture: Lessons for knowledge exchange and policy. Land use policy [Internet]. 2019;81(April 2017):834-42. Available from: https://doi.org/10.1016/j.landusepol.2018.11.001

[34]. Baloch MA, Thapa GB. Review of the agricultural extension modes and services with the focus to Balochistan, Pakistan. J Saudi Soc Agric Sci [Internet]. 2019;18(2):188-94. Available from: https://doi.org/10.1016/j.jssas.2017.05.001

[35]. Zasada I, Häfner K, Schaller L, van Zanten BT, Lefebvre M, Malak-Rawlikowska A, et al. A conceptual model to integrate the regional context in landscape policy, management and contribution to rural development: Literature review and European case study evidence. Geoforum [Internet]. 2017;82(July 2016):1-12. Available from: http://dx.doi.org/10.1016/j.geoforum.2017.03.012

[36]. Cabral L, Favareto A, Mukwereza L, Amanor K. Brazil's Agricultural Politics in Africa: More Food International and the Disputed Meanings of "Family Farming." World Dev. 2016;81:47-60.

[37]. M. Badrul Haider, Akhter T. Small and Medium Enterprises Financing in Bangladesh: the Missing Middle. 2014;4(4):295-308.

[38]. Kasus S, Sumatera DI, Kustiari R, Purba HJ. ANALISIS DAYA SAING MANGGIS INDONESIA DI PASAR DUNIA (STUDI KASUS DI SUMATERA BARAT) An Analysis of Indonesian Mangosteen Competitiveness in the World Market (A Case Study in West Sumatera). 2012;81-107.

[39]. Barhatov V, Campa A, Pletnev D. The Impact of Internet-Technologies Development on Small Business Success in Russia. Procedia - Soc Behav Sci [Internet]. 2018;238:552-61. Available from: https://linkinghub.elsevier.com/retrieve/pii/S1877042 $81830065 \mathrm{X}$
[40]. Raungpaka V, Savetpanuvong P. Information orientation of small-scale farmers' community enterprises in Northern Thailand. Kasetsart J Soc Sci [Internet]. 2017;38(3):196-203. Available from: https://doi.org/10.1016/j.kjss.2016.08.018

[41]. Rad. a Suitable Innovation Type To Improve the Added Value in Entrepreneurship. 2011;1(3):139-50.

[42]. Andriyanty R, Humaira L. The analysis of magosteen west java farmer marketing channel. 2016;2016(november):15-6.

[43]. Icc IPB. Integrating Bioresources and Advanced Technology for Sustainable Development THE 6 INTERNATIONAL SYMPOSIUM FOR. 2016;15-6.

[44]. Agbolade Obasan K. The Impact of Business Environment on the Survival of Small Scale Businesses in Nigeria. Int $\mathbf{J}$ Manag Bus Res. 2014;4(3):165-70.

[45]. R. Radfar. N. Rezaei-Malek. Improving Performance of Customer Relationship Management Through Applying Knowledge Management. 2012;2(2):13650.

[46]. Kotler P. Shaping The Market Offering. Mark Manag , [Millenium Ed. 2012;392-400.

[47]. Kaleka A, Morgan NA. How marketing capabilities and current performance drive strategic intentions in international markets. Ind Mark Manag [Internet]. 2019;78:108-21. Available from: https://doi.org/10.1016/j.indmarman.2017.02.001

[48]. Kyomugisha H, Sebatta C, Mugisha J. Potato market access, marketing efficiency and on-farm value addition in Uganda. Sci African [Internet]. 2018;1:e00013. Available from: https://doi.org/10.1016/j.sciaf.2018.e00013

[49]. Obradović V, Kostić SC, Mitrović Z. Rethinking Project Management - Did We Miss Marketing Management? Procedia - Soc Behav Sci [Internet]. 2016;226(October 2015):390-7. Available from: http://dx.doi.org/10.1016/j.sbspro.2016.06.203

[50]. Abishovna BA. The Principle of Effective Marketing Management. Procedia - Soc Behav Sci. 2014;109:1322-5.

[51]. Hussin MRA, Alias RA, Ismail K. An Action Research Approach for the Development of Cost Management Skills Training Programme among the Owners of Small and Medium Enterprises (SMEs) in Malaysia. Procedia - Soc Behav Sci. 2013;91:515-21.

[52]. Gangai KN, Agrawal R. Job satisfaction and organizational commitment: Is it important for employee performance. Int $\mathbf{J}$ Manag Bus Res [Internet]. 2015;5(4):269-78. Available from: http://www.ijmbr.org/article_7957_00f359f786fbf60d 13a40db3cc4b4497.pdf

[53]. Timm NH. 2002. Applied Multivariate Analysis. Springer. New York.

[54]. Ghosal, S. and Porkodi S. Reasons for Migration of Contract Labor To Oman: a Sem Approach. 2014;4(3):213-24.

[55]. Santiago A, Roxas F. Reviving Farming Interest in the Philippines Through Agricultural Entrepreneurship Education. J Agric Food Syst Community Dev. 2015;(July):1-13. 
[56]. Jamaluddin N. Adoption of E-commerce Practices among the Indian Farmers, a Survey of Trichy District in the State of Tamilnadu, India. Procedia Econ Financ. 2014;7(Icebr 2013):140-9.

[57]. Social Entrepreneurship As an Instrument To Empowering Small and Medium Enterprises: an Islamic Perspective. Int $\mathrm{J}$ Manag Bus Res. 2011;1(1):35-46.

[58]. Abdullah MA, Hoetoro A. Social Entrepreneurship as an Instrument to Empowering Small and Medium Enterprises : An Islamic Perspective. Int J Manag Bus Res. 2011;1(1):35-46.

[59]. Allahyari MS, Saburi MS, Keshavarz F. Analyzing farm management skills in poultry production enterprises in Iran. Life Sci J. 2011;8(1):61-7.

[60]. Lobonţiu G, Lobonţiu M. The Owner-manager and the Functional Management of a Small Firm. Procedia Soc Behav Sci. 2014;124(0):552-61.

[61]. Erlangga N, Purwadaria HK, Firdaus M. IMPROVEMENT OF MANGOSTEEN FARMING AND POSTHARVEST HANDLING STRATEGIES BASED ON GLOBAL GAP STANDARD AT KIARA PEDES , PURWAKARTA DISTRICT. 2012;9:69-77.

[62]. Sianipar CPM, Yudoko G, Adhiutama A, Dowaki K. Community Empowerment through Appropriate Technology: Sustaining the Sustainable Development. Procedia Environ Sci. 2013;17:1007-16.

[63]. Toader M, Roman GV. Family Farming - Examples for Rural Communities Development. Agric Agric Sci Procedia. 2015;6:89-94.

[64]. 2013 Annual Report on FAO's projects and activities in support of producer organizations and cooperatives. 2013;

[65]. Cofré-Bravo G, Klerkx L, Engler A. Combinations of bonding, bridging, and linking social capital for farm innovation: How farmers configure different support networks. J Rural Stud. 2019;69(May):53-64.

[66]. Marjanova TJ, Sofijanova E, Davcev L, Temjanovski R. Entrepreneurial Competition Orientation and Profitability: The Case of a Developing Economy. Procedia - Soc Behav Sci. 2015;207:652-61. 